\title{
High resistance to Sclerotinia sclerotiorum in transgenic soybean plants transformed to express an oxalate decarboxylase gene
}

\author{
W. G. Cunha ${ }^{a b}$, M. L. P. Tinoco ${ }^{a b}$, H. L. Pancoti ${ }^{a}$, R. E. Ribeiro ${ }^{a}$ and \\ F. J. L. Aragão ${ }^{a *}$ \\ ${ }^{a}$ Embrapa Recursos Genéticos e Biotecnologia, PqEB W5 Norte, 70770-916, Brasília; and ' Departamento de Biologia Celular, \\ Universidade de Brasília, Campus Universitário, 70910-900 Brasilia, DF, Brazil
}

Pathogenesis of Sclerotinia sclerotiorum (white mould) has been associated with fungal secretion of oxalic acid (OA). Enzymes capable of degrading OA have been utilized to produce transgenic resistant plants. Transgenic soybean lines containing the decarboxylase gene $(o x d c)$ isolated from a Flammulina sp. were produced by the biolistic process. Molecular analysis revealed successful incorporation of the gene into the plant genome and showed that the oxdc gene was transferred to the progeny plants. Sixteen $T_{2}$ transgenic events were screened for $S$. sclerotiorum resistance using a detached leaf assay. The white mould disease progress curve displayed a significant delay in symptom development in all oxdc events compared with the nontransgenic genotype. Area under the disease progress curve (AUDPC) showed reduction in severity ranging from $61 \%$ to $96 \%$ comparing the oxdc events with the nontransgenic control. One event (OXDC.9.21) presented some plants that did not show any symptoms after $92 \mathrm{~h}$. RT-PCR analysis for detection of $o x d c$ gene transcripts suggested that expression of the $o x d c$ gene is associated with resistance to S. sclerotiorum.

Keywords: oxalate decarboxylase, oxalic acid, transgenic soybean, white mould

\section{Introduction}

White mould, caused by the necrotrophic ascomycete fungus Sclerotinia sclerotiorum, is a worldwide disease. The fungus infects more than 400 plant species, including important crops such as cotton, tomato, sunflower, dry bean and soybean (Boland \& Hall, 1994). In soybean, the disease is also called sclerotinia stem rot (SSR) and its incidence causes significant damage to yield and grain quality. For an increase of $10 \%$ in disease incidence the yield losses range from 83 to $335 \mathrm{~kg} \mathrm{ha}^{-1}$ (Danielson et al., 2004). SSR is one of the most important soybean diseases in the USA and Brazil and these countries are responsible for more than $60 \%$ of total world soybean production. In the USA, SSR is generally found in farms in the states of Iowa, Illinois, Minnesota, Nebraska and Pennsylvania (Wrather \& Koenning, 2009). Historically, these states produce about $55 \%$ of the total soybean produced in the USA (http://www.nass.usda.gov/ Statistics_by_Subject/index.asp). In 2004, when climatic conditions were favourable to the pathogen's development, the soybean yield suppression caused by SSR was

*E-mail: aragao@cenargen.embrapa.br

Published online 18 March 2010 more than 60 million bushels (Wrather \& Koenning, 2009). In Brazil, the disease usually occurs in the southern states and in highland areas of the Central Region. In these regions, yield losses of up to $60 \%$ have been verified (L.H.C. da Silva, FESURV, Brazil, personal communication).

Disease control management is concentrated on agronomic practices, such as planting under tillage, use of lodging resistant varieties, wide-row planting and rotation with non-host crops. However, in favourable environmental conditions for pathogen development, these practices are not enough. Recommended chemical control has poor efficiency due to low penetration and uneven distribution of fungicides, caused by the already formed plant canopy, since the infection starts at the plant's reproductive stage. Additionally, the use of fungicides for SSR control increases production costs. Consequently, resistant varieties would be the best alternative for SSR management. However, such a disease is difficult to control genetically where breeding programmes have had limited success. Genetic resistance to $S$. sclerotiorum is complex, has low heritability and is restricted to a few lines that have shown only partial resistance (Kim \& Diers, 2000; Vuong et al., 2008). In addition, the plant escape mechanisms (flowering date, plant height, lodging, canopy architecture and maturity) and environmental conditions make SSR resistance evaluations difficult in the field. 
Previous studies showed that some of the identified quantitative trait loci (QTL) for resistance to SSR were associated with escape mechanisms (Kim \& Diers, 2000). For these reasons, soybean breeding has not made available a SSR-resistant variety on the market.

Previous studies provided evidence for the involvement of oxalic acid (OA) in S. sclerotiorum pathogenesis and OA tolerance has been correlated to disease tolerance (Bateman \& Beer, 1965; Maxwell \& Lumsden, 1970; Noyes \& Hancock, 1981; Marciano et al., 1983; Magro et al., 1984; Tu, 1985; Godoy et al., 1990; Wegulo et al., 1998; Cessna et al., 2000; Kolkman \& Kelly, 2000; Favaron et al., 2004; Guimarães \& Stotz, 2004; Kim et al., 2008; Walz et al., 2008b). Treatment of healthy plants with OA or fungal culture filtrates resulted in foliar symptoms identical to those found in diseased plants (Bateman \& Beer, 1965; Noyes \& Hancock, 1981; Marciano et al. 1983). In addition, plants that showed in vitro and field tolerance to OA were more tolerant to $S$. sclerotiorum (Noyes \& Hancock, 1981; Tu, 1985; Wegulo et al., 1998; Kolkman \& Kelly, 2000) and mutants of S. sclerotiorum unable to synthesize OA were less pathogenic when compared with a wild type (Godoy et al., 1990). A potential alternative to developing an SSR-resistant soybean variety is the introduction of genes that generate enzymes capable of degrading the OA. Several transgenic plants expressing genes encoding enzymes that can metabolize OA, such as oxalate oxidases (OXO) and oxalate decarboxylases (OXDC), have shown an enhanced resistance to $S$. sclerotiorum (Kesarwani et al., 2000; Donaldson et al., 2001; Cober et al., 2003; Hu et al., 2003; Livingstone et al., 2005; Dias et al., 2006; Dong et al., 2008; Walz et al., 2008a). OXO catalyses the oxygen-dependent oxidation of oxalate to carbon dioxide and hydrogen peroxide. OXDC breaks down oxalate to generate carbon dioxide and formate in the absence of any cofactor requirement. In addition, OXDC is specific to $\mathrm{OA}$ and has high activity at acidic or neutral $\mathrm{pH}$ (Kesarwani et al., 2000).

The main goal of this research was to introduce an oxalate decarboxylase gene $(o x d c)$ from a Flammulina sp. into the soybean genome in order to generate transgenic lines resistant to $S$. sclerotiorum.

\section{Materials and methods}

\section{Plasmid vector and soybean transformation}

The oxdc coding sequence was removed from pTOPOOxDc and cloned into the vector pUC19-35SdAMV-

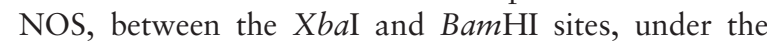
control of the doubled $35 \mathrm{~S}$ promoter from Cauliflower mosaic virus and a sequence enhancer from Alfalfa mosaic virus (Dias et al., 2006). The oxdc expression cassette was excised with EcoRI and HindIII from the vector pOXDC (Dias et al., 2006) and inserted into the pBluKSP (Fermentas) to generate the pBluKSPOXDC vector. The $o x d c$ cassette is composed of the oxdc coding sequence under control of the doubled $35 \mathrm{~S}$ promoter from Cauli-

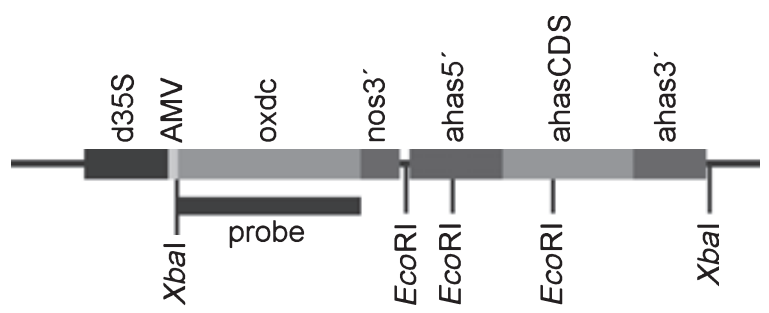

Figure 1 Diagram representing the pBluKSPOXDCAHAS transformation vector containing the ahas gene (ahas5': ahas gene promoter; ahasCDS: Arabidopsis thaliana AHAS coding sequence; ahas3': ahas gene terminator) and oxdc expression cassettes (d35S: doubled 35S promoter from Cauliflower mosaic virus; AMV: non-translated sequence enhancer from Alfalfa mosaic virus; nos3': nopaline synthase terminator). Black bar represents the probe used in the Southern analysis.

flower mosaic virus and a sequence enhancer from Alfalfa mosaic virus, and nos gene terminator. The 5718-bp fragment containing the mutated Arabidopsis ahas gene (selectable marker that confers imidazolinone-specific resistance) was removed with $\mathrm{XbaI}$ from the vector pAC321 (Rech et al., 2008) and cloned into the SpeI site of the vector pBluKSPOXDC, resulting in the transformation vector pBluKSPOXDCAHAS (Fig. 1).

Soybean transformation was carried out according to Rech et al. (2008) and Aragão et al. (2000). Mature seeds of a commercial variety (BR-16) were surface-sterilized and soaked in distilled water for 18-20 h. The embryonic axes were excised from seeds, and the apical meristems were exposed by removing the primary leaves and bombarded as previously described by Aragão et al. (2000). Multiple shooting was induced by cultivating the embryonic axes in BAP-supplemented medium immediately after bombardment. As soon as the embryonic axesderived shoots were $2-3 \mathrm{~cm}$ in length, they were individually transferred to a plastic pot containing a mixture of fertilized soil and vermiculite and acclimatized in a greenhouse to produce seeds. A total of 1152 explants were bombarded with the vector pBluKSPOXDCAHAS.

\section{PCR screening of transformed plants}

The recovered plants and progenies were screened by PCR to detect the presence of the oxdc gene. Genomic DNA from young leaves was extracted by the CTAB method (Doyle \& Doyle, 1987). The PCR analyses were carried out according to Aragão et al. (2002). The primers OXDC 371 (5'-CTCGGCAGCAGAATGAGGTC-3') and OXDC 873 (5'-TCGGCTCGACAGAGGAGAAG-3') were used to amplify a 522-bp sequence within the $o x d c$ coding sequence.

\section{Detached leaf assays}

The detached leaf assay was carried out using plants from the $\mathrm{T}_{2}$ generation. Sclerotia were collected from a soybean infected field located in Distrito Federal (Brazil) and 
cultured on potato dextrose agar (PDA) medium at room temperature to produce mycelia. To produce the inoculum for the detached leaf assays, a single $5 \mathrm{~mm}$ diameter mycelium plug was placed at the centre of a new PDA plate. The fresh culture was incubated at $20^{\circ} \mathrm{C}$ for 2 days in the dark. Mycelial plugs with $5 \mathrm{~mm}$ diameter were cut from the growing margins and applied to the adaxial surface of the middle leaflet of the youngest fully-expanded trifoliate leaves detached from plants (at V3 stage, according to Fehr et al., 1971). Leaves were immediately placed on a Petri dish containing three moist filter papers and incubated at $20^{\circ} \mathrm{C}$ in the dark. Leaves were photographed at three different times (42, 66 and $90 \mathrm{~h}$ ) and images were used to measure the infected area using the QUANT v1.0.1 software (Vale et al., 2003). The area under the disease progress curve (AUDPC) was used to summarize the progress of disease severity according to Shaner \& Finney (1977).

\section{Southern blot analysis}

Genomic DNA was isolated according to Dellaporta et al. (1983). Southern blotting and hybridization were carried out as previously described (Sambrook et al., 1989). Genomic DNA (15 $\mu \mathrm{g})$, digested with EcoRI, was separated on a $1 \%$ agarose gel, blotted onto a nylon membrane (Hybond) and hybridized with the probe labelled with $\alpha\left[{ }^{32} \mathrm{P}\right]$-dCTP $\left(3000 \mathrm{Ci} \mathrm{mol}^{-1}\right)$ using a random primer DNA labelling kit (Pharmacia Biotech) according to the manufacturer's instructions. The probe was obtained by digesting the pBluKSPOXDCAHAS with BamHI and $\mathrm{XbaI}$ to generate the 1350-bp fragment (corresponding to $o x d c$ coding sequence) that was isolated from a $1 \%$ agarose gel and purified using the Wizard SV Gel CleanUp System (Promega).

\section{RT-PCR expression analysis}

RT-PCR were carried out as described by Dias et al. (2006). The relative intensity of the bands was determined by scanning the PCR gel and analyzing the band intensity using the Quantity One ${ }^{\circledR}$ program v4.6.3. Relative quantification was done by comparing intensities of the $o x d c$ and $18 \mathrm{~S}$ rRNA bands.

\section{Results}

PCR analyses revealed the presence of the oxdc gene in 10 generated plantlets (Fig. 2). Each of the 10 oxdc plants was considered a distinct $\mathrm{T}_{0}$ event (named OXDC.1 to OXDC.10). All seeds from the $\mathrm{T}_{0}$ events were planted in a greenhouse and the $T_{1}$ plants were screened by PCR to detect the presence of the oxdc gene. Transformants presented phenology (plant height, site of insertion of first pod, number of branches, internode length, foliar area, total number of flowers and pods) similar to the non-transformed plants. Seeds from $16 \mathrm{~T}_{1}$ events (OXDC.1.01; OXDC.1.02; OXDC.2.03; OXDC.2.04; OXDC.3.05; OXDC.3.06; OXDC. 4.07; OXDC.4.08; OXDC.5.09; OXDC.5.10; OXDC. 6.11; OXDC.6.12; OXDC.7.16; OXDC.7.17; OXDC.8.18 and OXDC.9.21) were harvested to plant the $\mathrm{T}_{2}$ generation.

About 10 PCR-positive plants of each oxdc event and 10 plants of the nontransgenic variety BR-16, which showed similar growing development in the greenhouse, were screened for $S$. sclerotiorum resistance using the detached leaf assay. The disease progress curve displayed a significant delay in the symptom development in all oxdc events compared with the nontransgenic genotype (Fig. 3). Some plants of the event OXDC.9.21 did not show any symptoms after $92 \mathrm{~h}$. Extensive mycelia penetration was not observed using a stereomicroscope over a period of $90 \mathrm{~h}$ or even after $114 \mathrm{~h}$ (Fig. $4 \mathrm{j}-\mathrm{k}$ ). In the control plants, the lesions expanded across the whole leaf after $90 \mathrm{~h}$ (Fig. 4). The average of the infected area $90 \mathrm{~h}$ after inoculation ranged from $0.45 \mathrm{~cm}^{2}$ (OXDC.9.21) to $7 \cdot 19 \mathrm{~cm}^{2}$ (OXDC.2.03) in the transgenic events, while in the control it was $17 \cdot 60 \mathrm{~cm}^{2}$. The AUDPC showed a severity reduction of $96 \%$ (OXDC.9.21) to $61 \%$ (OXDC.2.03) comparing the oxdc events with the nontransgenic control.

RT-PCR analysis for detection of $o x d c$ gene transcripts was carried out with one plant from event OXDC.9.21 (that exhibited the highest resistance to $S$. sclerotiorum), one plant of OXDC.6.11 (that presented partial resistance) and one of the nontransgenic genotypes. The transgenic events showed $o x d c$ gene expression, while in the nontransgenic plant $o x d c$ transcripts were not observed (Fig. 5).

Since the event OXDC.9.21 revealed the highest $S$. sclerotiorum resistance, it was selected for further characterization by Southern blot. Results revealed the presence of two integrated copies of the oxdc gene and that all transgenic plants analyzed from this event presented the same integration pattern (Fig. 6). DNA isolated from a nontransgenic plant did not hybridize with the oxdc coding sequence probe.

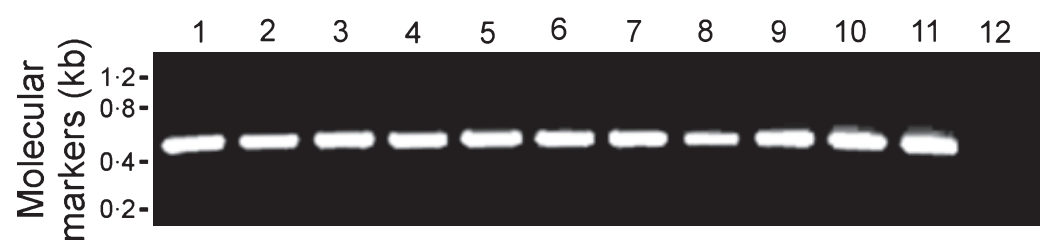

Figure 2 PCR analysis of putative transformed soybean plants for detection of the oxdc gene. Lanes 1-10: transgenic lines; lane 11: vector pBluKSPOXDCAHAS; lane 12: nontransgenic plant. 
Figure 3 Disease progress curve of $T_{2}$ oxdc soybean transgenic events and the nontransgenic control (BR-16) obtained by the detached leaf assay using Sclerotinia sclerotiorum mycelial agar plug. The infected area measured in each time was an average of 10 different plant repetitions except for the OXDC.1.02, OXDC.2.04, OXDC.5.10 OXDC.7.16, OXDC.7.17 and OXDC.8.18 that were $9,6,4,8,6$ and 9 repetitions, respectively. Bars $=$ standard deviation.
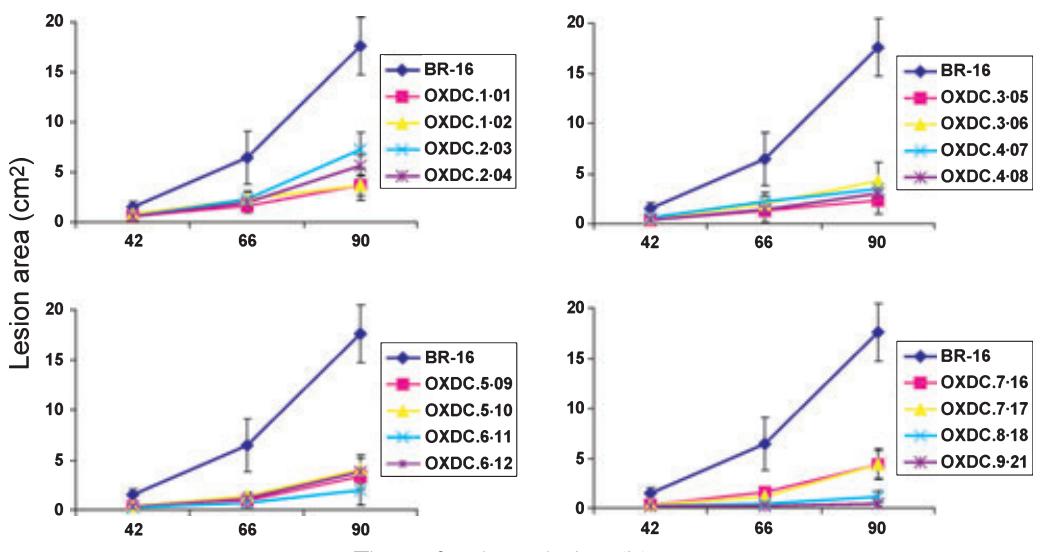

Time after inoculation (h)
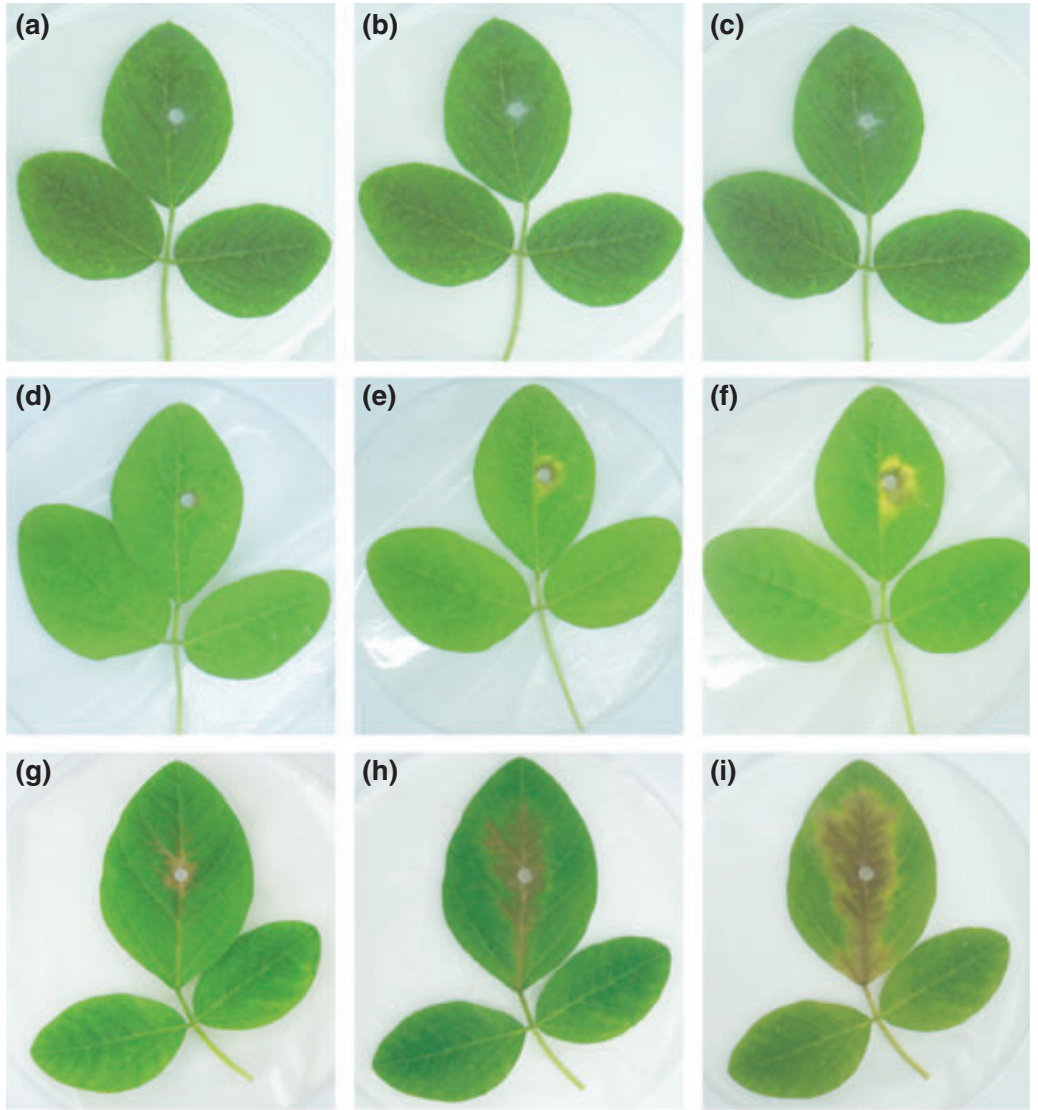

plants to Sclerotinia sclerotiorum inoculation. Symptoms were observed on detached leaves $42 \mathrm{~h}$ ( $\mathrm{a}, \mathrm{d}$ and $\mathrm{g}$ ), $66 \mathrm{~h}$ (b, e and h) and $90 \mathrm{~h}(\mathrm{c}, \mathrm{f}$ and $\mathrm{i})$ after inoculation of transgenic plants OXDC.9.21.2 (a-c), OXDC.6.11.7, (d-f) and nontransgenic control ( $\mathrm{g}-\mathrm{i})$ with 5-mm mycelial agar plugs. Detail of soybean line OXDC.9.21.2 response to the mycelium of $S$. sclerotiorum growth $90 \mathrm{~h}(\mathrm{j})$ and $114 \mathrm{~h}(\mathrm{k})$ after inoculation compared to a nontransgenic plant $90 \mathrm{~h}$ after inoculation (I).
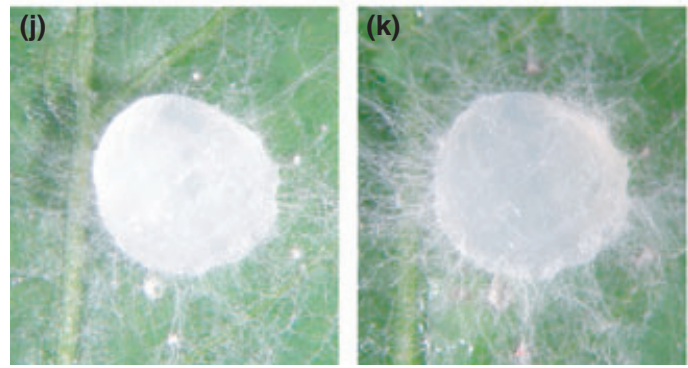


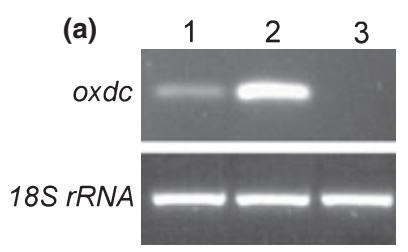

(b)

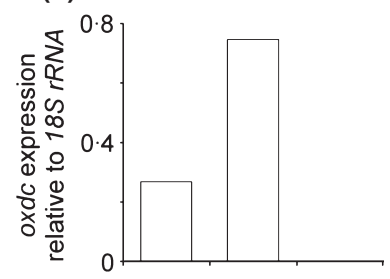

Figure 5 (a) RT-PCR for detection of expression of the foreign oxdc and endogenous $18 S$ rRNA genes in transgenic soybean lines. (b) Quantification of the oxdc gene expression relative to that of $18 \mathrm{~S}$ rRNA housekeeping gene. Lane 1: line OXDC.6.11.7; lane 2: line OXDC.9.21.2; lane 3: nontransgenic plant.

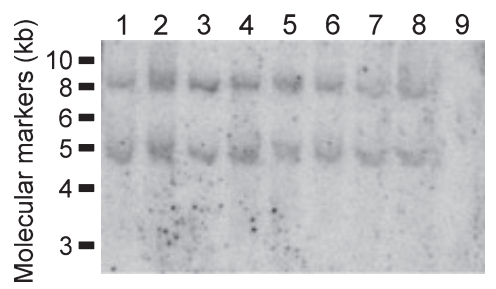

Figure 6 Southern blot analysis of genomic DNA to detect the foreign oxdc gene expression cassette in the soybean plants $\left(T_{2}\right.$ generation) from transgenic event OXDC.9.21. Lanes 1-8: transgenic plants; lane 9: nontransgenic plant.

\section{Discussion}

The progenies ( $\mathrm{T}_{2}$ generation) of self-pollinated transgenic lines were tested for resistance to $S$. sclerotiorum. Results from the detached leaf assays showed that plants transformed with the oxdc gene presented different levels of resistance to $S$. sclerotiorum. Compared to the nontransformed control, all transgenic events demonstrated a significant delay in lesion development. Similar results were previously reported in tobacco, tomato and lettuce transgenic plants transformed to express an oxdc coding gene (Kesarwani et al., 2000; Dias et al., 2006; Walz et al., 2008a).

RT-PCR analysis revealed the expression of the oxdc gene in the resistant lines tested (OXDC.9.21.2, OXDC.6.11.7), while no transcripts corresponding to the $o x d c$ gene were observed in the susceptible nontransgenic lines analyzed. Results suggested that line OXDC.6.11.7, exhibiting only moderate resistance to $S$. sclerotiorum, revealed a presence of $o x d c$ gene transcripts at a much lower level (Fig. 5b) than observed in the line OXDC.9.21.2, which exhibited a high resistance level to the pathogen. These results suggest that expression of the $o x d c$ gene is associated with resistance to the fungus and that the resistance level is dependent on the transgene expression level. The association of the presence of the gene and resistance is also supported by the fact that all transgenic lines presented a level of resistance to the pathogen while all nontransgenic genotypes tested were susceptible to infection. The results have shown that the generation of highly $S$. sclerotiorum-resistant soybean lines is feasible by the expression of the oxalate decarboxylase gene. The interaction of Sclerotinia with epidermal cells of transgenic and nontransgenic soybean plants is currently being studied at the ultra-structural level. This may help to elucidate the cellular basis of this plant-pathogen interaction. In addition, studies will be carried out to evaluate the resistance of soybean lines under field conditions. To confirm the enhanced resistance shown by the detached leaf assay, transgenic event OXDC.9.21 will be further tested under field conditions. Although the values were inconsistent in some situations, a significant correlation of SSR disease ratings between the detached leaf assay and field evaluations has been reported (Wegulo et al., 1998; Kim et al., 2000; Hoffman et al., 2002). To ensure the consistency of the detached leaf assay, this study used uniform leaf size, fixed the inoculum placement and provided adequate moisture during the test, as discussed by Wegulo et al. (1998).

Expression of oxalate-detoxifying enzymes in transgenic plants has been successful in generating resistant lines. Wheat oxalate oxidase has been constitutively expressed in canola, tobacco, soybean, poplar, sunflower, peanut and tomato (Thompson et al., 1995; Berna \& Bernier, 1997; Donaldson et al., 2001; Cober et al., 2003; Hu et al., 2003; Livingstone et al., 2005; Dong et al., 2008) and the oxalate decarboxylase gene has been incorporated into tobacco, tomato and lettuce (Kesarwani et al., 2000; Dias et al., 2006; Walz et al., 2008a). In contrast to oxalate oxidase enzyme activity, which converts $\mathrm{OA}$ into carbon dioxide and hydrogen peroxide, oxalate decarboxylase promotes OA conversion into carbon dioxide and formate and does not lead to a development of additional hydrogen peroxide (Kesarwani et al., 2000; Walz et al., 2008a). The production of oxygen radical synthesis interactions seems to be important, as they weaken the host tissue at early stages of infection and consequently enhance the growth and development of the pathogen (Govrin \& Levine, 2000). Kim et al. (2008) concluded that $S$. sclerotiorum-secreted oxalate induces increased levels of reactive oxygen species (ROS) such as hydrogen peroxide and superoxide in the plant in the early stages of the infection, which appears to trigger a programmed cell death (PCD) pathway, resulting in plant cell death and the generation of a suitable environmental niche for fungal pathogenic development, nutrient acquisition, and the establishment of a necrotrophic relationship. Walz et al. (2008b) observed moderate hydrogen peroxide accumulation in inoculated tobacco plants in the first $24 \mathrm{~h}$ after infection and a subsequent decrease. These studies suggested that in the early stages of pathogenesis at relatively high $\mathrm{pH}(>5)$ the oxalate produced by the fungus induces increased reactive oxygen species 
(hydrogen peroxide and superoxide) levels and a programmed cell death response in plant tissue that is required for disease development (Kim et al., 2008). As $\mathrm{OA}$ accumulates, the $\mathrm{pH}$ decreases and it suppresses the reactive oxygen species and programmed cell death, enabling the pathogen's further ingress into plant tissue (Kim et al., 2008). OXDC transgenic plants would be a better model in which to study the plant pathogen interaction, considering that there is no additional hydrogen peroxide production, unlike in OXO plants. In practical terms, more studies are needed to determine which oxalate-detoxifying strategy would be more appropriate.

\section{Acknowledgements}

We gratefully acknowledge the financial support of FINEP and CNPq (Conselho Nacional de Desenvolvimento Científico e Tecnológico, grant number 500028/ 2006-0). W. Cunha was supported by a fellowship from CNPq.

\section{References}

Aragão FJL, Sarokin L, Vianna GR, Rech EL, 2000. Selection of transgenic meristematic cells utilizing a herbicidal molecule results in the recovery of fertile transgenic soybean (Glycine max (L.) Merrill) plants at a high frequency. Theoretical and Applied Genetics 101, 1-6.

Aragão FJL, Vianna GR, Albino MMC, Rech EL, 2002. Transgenic dry bean tolerant to the herbicide glufosinate ammonium. Crop Science 42, 1298-302.

Bateman DF, Beer SV, 1965. Simultaneous production and synergistic action of oxalic acid and polygalacturonase during pathogenesis by Sclerotium rolfsii. Phytopathology 55, 204-11.

Berna A, Bernier F, 1997. Regulated expression of a wheat germin gene in tobacco: oxalate oxidase activity and apoplastic localization of the heterologous protein. Plant Molecular Biology 33, 417-29.

Boland GJ, Hall R, 1994. Index of plant hosts of Sclerotinia sclerotiorum. Canadian Journal of Plant Pathology 16, 93-100.

Cessna SG, Sears VE, Dickman MB, Low PS, 2000. Oxalic acid, a pathogenicity factor for Sclerotinia sclerotiorum, suppresses the oxidative burst of the host plant. The Plant Cell 12, 2191-9.

Cober ER, Rioux S, Rajcan I, Donaldson PA, Simmonds DH, 2003. Partial resistance to white mold in a transgenic soybean line. Crop Science 43, 92-5.

Danielson GA, Nelson BD, Helms TC, 2004. Effect of Sclerotinia stem rot on yield of soybean inoculated at different growth stages. Plant Disease 88, 297-300.

Dellaporta SL, Wood J, Hicks JB, 1983. A plant DNA minipreparation: Version II. Plant Molecular Biology Reporter 1, 19-21.

Dias BBA, Cunha WG, Morais LS et al., 2006. Expression of an oxalate decarboxylase gene from Flammulina sp. in transgenic lettuce (Lactuca sativa) plants and resistance to Sclerotinia sclerotiorum. Plant Pathology 55, 187-93.

Donaldson PA, Anderson T, Lane BG, Davidson AL, Simmonds $\mathrm{DH}, 2001$. Soybean plants expressing an active oligomeric oxalate oxidase from the wheat $g f-2.8$ (germin) gene are resistant to the oxalate-secreting pathogen Sclerotina sclerotiorum.

Physiological and Molecular Plant Pathology 59, 297-307.

Dong X, Ji R, Guo X et al., 2008. Expressing a gene encoding wheat oxalate oxidase enhances resistance to Sclerotinia sclerotiorum in oilseed rape (Brassica napus). Planta 228, 33140.

Doyle JJ, Doyle JL, 1987. Genomic plant DNA preparation from fresh tissue: CTAB method. Phytochemical Bulletin 19, 11-4.

Favaron F, Sella L, D’Ovidio R, 2004. Relationships among endopolygalacturonase, oxalate, $\mathrm{pH}$, and plant polygalacturonaseinhibiting protein (PGIP) in the interaction between Sclerotinia sclerotiorum and soybean. Molecular Plant-Microbe Interactions 17, 1402-9.

Fehr WR, Caviness CE, Burmood DT, Pennington JS, 1971. Stage of development descriptions for soybeans, Glycine max (L.) Merrill. Crop Science 11, 929-31.

Godoy G, Steadman JR, Dickman MB, Dam R, 1990. Use of mutants to demonstrate the role of oxalic acid in pathogenicity of Sclerotinia sclerotiorum on Phaseolus vulgaris. Physiological and Molecular Plant Pathology 37, 179-91.

Govrin EM, Levine A, 2000. The hypersensitive response facilitates plant infection by the necrotrophic pathogen Botrytis cinerea. Current Biology 10, 751-7.

Guimarães RL, Stotz HU, 2004. Oxalate production by Sclerotinia sclerotiorum deregulates guard cells during infection. Plant Physiology 136, 3703-11.

Hoffman DD, Diers BW, Hartman GL et al., 2002. Selected soybean plant introductions with partial resistance to Sclerotinia sclerotiorum. Plant Disease 86, 971-80.

Hu X, Bidney DL, Yalpani N et al., 2003. Overexpression of a gene encoding hydrogen peroxide-generating oxalate oxidase evokes defense responses in sunflower. Plant Physiology 133, 170-81.

Kesarwani M, Azam M, Natarajan K, Mehta A, Datta A, 2000. Oxalate decarboxylase from Collybia velutipes. Molecular cloning and its overexpression to confer resistance to fungal infection in transgenic tobacco and tomato. Journal of Biological Chemistry 275, 7230-8.

Kim HS, Diers BW, 2000. Inheritance of partial resistance to sclerotinia stem rot in soybean. Crop Science 40, 55-61.

Kim KS, Dickman MB, Min JY, 2008. Oxalic acid is an elicitor of plant programmed cell death during Sclerotinia sclerotiorum disease development. Molecular Plant-Microbe Interactions 21, 605-12.

Kim HS, Hartman GL, Manandhar JB, Graef GL, Steadman JR, Diers BW, 2000. Reaction of soybean cultivars to Sclerotinia stem rot in field, greenhouse, and laboratory evaluations. Crop Science 40, 665-9.

Kolkman JM, Kelly JD, 2000. An indirect test using oxalate to determine physiological resistance to white mold in common bean. Crop Science 40, 281-5.

Livingstone DM, Hampton JL, Phipps PM, Grabau EA, 2005. Enhancing resistance to Sclerotinia minor in peanut by expressing a barley oxalate oxidase gene. Plant Physiology 137, 1354-62.

Magro P, Marciano P, Di Lenna P, 1984. Oxalic acid production and its role in pathogenesis of Sclerotinia sclerotiorum. FEMS Microbiology Letters 24, 9-12.

Marciano P, Di Lenna P, Magro P, 1983. Oxalic acid, cell walldegrading enzymes and $\mathrm{pH}$ in pathogenesis and their significance 
in the virulence of two Sclerotinia sclerotiorum isolates on sunflower. Physiological Plant Pathology 22, 339-45.

Maxwell DP, Lumsden RD, 1970. Oxalic acid production by Sclerotinia sclerotiorum in infected bean and in culture. Phytopathology 60, 1395-8.

Noyes RD, Hancock JG, 1981. Role of oxalic acid in the Sclerotinia wilt of sunflower. Physiological Plant Pathology 18, 123-32.

Rech EL, Vianna GR, Aragão FJL, 2008. High-efficiency transformation by biolistics of soybean, common bean and cotton transgenic plants. Nature Protocols 3, 410-8.

Sambrook J, Fritsch EF, Maniatis T, 1989. Molecular Cloning: A Laboratory Manual. Cold Spring Harbor, NY, USA: Cold Spring Harbor Laboratory Press.

Shaner G, Finney RE, 1977. The effect of nitrogen fertilization on the expression of slow-mildewing resistance in Knox wheat. Phytopathology 67, 1051-6.

Thompson C, Dunwell JM, Johnstone CE et al., 1995. Degradation of oxalic acid by transgenic oilseed rape plants expressing oxalate oxidase. Euphytica 85, 169-72.

Tu JC, 1985. Tolerance of white bean (Phaseolus vulgaris) to white mold (Sclerotinia sclerotiorum) associated with tolerance to oxalic acid. Physiological Plant Pathology 26, 111-7.
Vale FXR, Fernandes Filho EI, Liberato JR, 2003. QUANT. A software for plant disease severity assessment. In: 8 th International Congress of Plant Pathology. Christchurch, New Zealand: 105.

Vuong TD, Diers BW, Hartman GL, 2008. Identification of QTL for resistance to sclerotinia stem rot in soybean plant introduction 194639. Crop Science 48, 2209-14.

Walz A, Zingen-Sell I, Loeffler M, Sauer M, 2008a. Expression of an oxalate oxidase gene in tomato and severity of disease caused by Botrytis cinerea and Sclerotinia sclerotiorum. Plant Pathology 57, 453-8.

Walz A, Zingen-Sell I, Theisen S, Kortekamp A, 2008b. Reactive oxygen intermediates and oxalic acid in the pathogenesis of the necrotrophic fungus Sclerotinia sclerotiorum. European Journal of Plant Pathology 120, 317-30.

Wegulo SN, Yang XB, Martinson CA, 1998. Soybean cultivar responses to Sclerotinia sclerotiorum in field and controlled environment studies. Plant Disease 82, 1264-70.

Wrather JA, Koenning SR, 2009. Effects of diseases on soybean yields in the United States 1996 to 2007. Plant Health Progress. doi:10.1094/PHP-2009-0401-01-RS. 